\title{
Decrease in endogenous CGRP release in nitroglycerin tolerance: Role of ALDH-2
}

\author{
Yue-Rong Chen, Sheng-Dan Nie, Wang Shan, De-Jian Jiang, Rui-Zheng Shi, \\ Zhi Zhou, Ren Guo, Zhe Zhang, Yuan-Jian Li * \\ Department of Pharmacology, School of Pharmaceutical Sciences, Central South University, Changsha 410078, China \\ Received 25 December 2006; received in revised form 3 May 2007; accepted 15 May 2007 \\ Available online 5 June 2007
}

\begin{abstract}
In the present study, we tested whether the decreased release of calcitonin gene-related peptide (CGRP) observed in nitroglycerin tolerance is associated with the decrease in aldehyde dehydrogenase (ALDH-2) activity. We further investigated the possible involvement of reactive oxygen species in the decrease in ALDH-2 activity. Tolerance was induced by exposure of isolated rat thoracic aortas and human umbical vein endothelial cells (HUVEC) to nitroglycerin in vitro or by pretreatment with nitroglycerin for 8 days in vivo. Pretreatment with ALDH-2 inhibitors and nitroglycerin significantly attenuated vasodilator responses to nitroglycerin concomitantly with a decrease in the release of CGRP from the isolated thoracic aorta. Nitroglycerin produced a depressor effect concomitantly with an increase in plasma concentrations of CGRP, and the effect of nitroglycerin was attenuated after pretreatment with an inhibitor of ALDH-2 or nitroglycerin for 8 days. Exposure of HUVEC to nitroglycerin for $16 \mathrm{~h}$ increased reactive oxygen species production and decreased ALDH-2 activity as well as cGMP production in a time-and concentration-dependent manner. Pretreatment with an ALDH-2 inhibitor also significantly decreased the cGMP production. However, tolerance to nitroglycerin in HUVEC was restored in the presence of $\mathrm{N}$-acetylcysteine or captopril. The present results suggest that nitrate tolerance is, at least partially, associated with a decrease in endogenous CGRP release via a decrease in ALDH-2 activity as a result of stimulation of reactive oxygen species production.
\end{abstract}

(C) 2007 Elsevier B.V. All rights reserved.

Keywords: Nitrate tolerance; Reactive oxygen species; Aldehyde dehydrogenase; Calcitonin gene-related peptide

\section{Introduction}

Nitroglycerin is a classical drug used against angina pectoris. Nitroglycerin is converted in the vasculature to NO or a closely related molecule, which activates guanylate cyclase and subsequently elevates the cyclic GMP (cGMP) level, resulting in vasodilation (Katsuki et al., 1977). However, long-term administration of nitroglycerin can cause the development of tolerance. The mechanisms responsible for tolerance to nitroglycerin are not clearly understood. Studies have showen that the mitochondrial isoform of aldehyde dehydrogenase (ALDH-2) is the main enzyme responsible for nitroglycerin bioactivation and has a specific role in cGMP-mediated, nitroglycerin-induced vasor-

\footnotetext{
* Corresponding author. Dept. of Pharmacology School of Pharmaceutical Sciences Central South University Xiang-Ya Road \#110 Changsha 410078, China. Tel.: +86 731 2355078; fax: +86 7312355078 .

E-mail address: yuan_jianli@yahoo.com (Y.-J. Li).
}

elaxation (Chen et al., 2002; Sydow et al., 2004). It has been shown that nitrate tolerance is induced by inhibition of ALDH-2 (Chen et al., 2002; Sydow et al., 2004).Considerable evidence shows that nitrate tolerance is closely related to oxidative stress induced by an increased production of reactive oxygen species (Munzel et al., 1999; Jurt et al., 2001; Csont and Ferdinandy, 2005; Wenzel et al., 2007). It is likely that nitroglycerin induces the production of reactive oxygen species, with a subsequent decrease in mitochondrial ALDH-2 activity, resulting in nitrate tolerance (Chen et al., 2002; Sydow et al., 2004).

Calcitonin gene-related peptide (CGRP), the principal transmitter in capsaicin-sensitive sensory nerves, is widely distributed in vascular tissues and is a potent vasodilator (Franco-Cereceda, 1988). Previous studies have suggested that nitroglycerin can evoke the release of CGRP from capsaicin-sensitive sensory nerves (Wei et al., 1992; Hu et al., 1999; Zhou et al., 2001a; Du et al., 2004; Ghatta and O'Rourke, 2006). We and others have also shown that CGRP mediates the depressor effect and vasodilation 


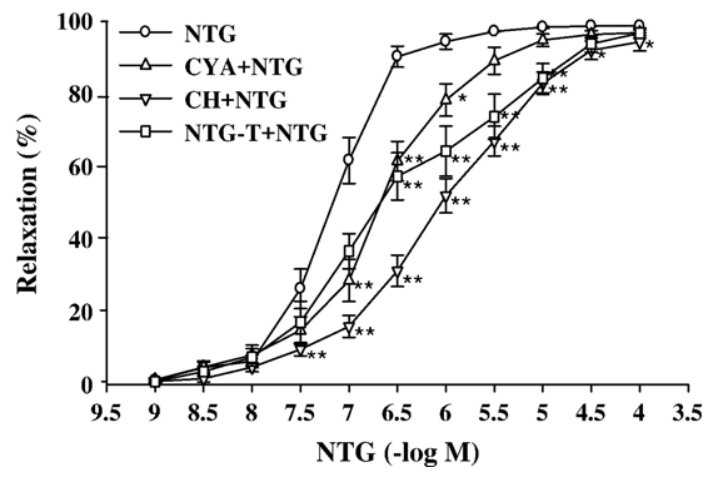

Fig. 1. Effect of ALDH2 inhibitors on vasodilator responses to nitroglycerin (NTG). Tolerance was induced by pretreatment with NTG $\left(10^{-5} \mathrm{M}\right)$ for $30 \mathrm{~min}$. For chloral hydrate $(\mathrm{CH})$ or cyanamide (CYA), preparations were treated with $\mathrm{CH}(1 \mathrm{mM})$ or CYA $(1 \mathrm{mM})$ for $15 \mathrm{~min}$ before treatment with NTG. Values are expressed as means \pm S.E.M. $(n=8-9),{ }^{*} P<0.05$ vs. NTG, ${ }^{* *} P<0.01$ vs. NTG.

produced by nitroglycerin via the cGMP pathway (Zhou et al., 2001a; Booth et al., 2000), and that the decreased depressor effect of nitroglycerin in tolerant states is also related to a decrease in CGRP release (Oroszi et al., 1999; Zhou et al., 2001b; Ghatta and O'Rourke, 2006). Some antioxidants such as $N$-acetylcysteine or captopril could reverse nitrate tolerance concomitantly with an increase in the release of CGRP (Zhou et al., 2001c). In the present study, therefore, we tested whether the decreased release of CGRP in nitroglycerin tolerance is due to decreased ALDH-2 activity as a result of stimulation of reactive oxygen species production.

\section{Materials and methods}

Male Wistar rats weighing 280 to $320 \mathrm{~g}$ were obtained from Central South University Animal Center. Animals received humane care in compliance with the "Guide for the Care and Use of Laboratory Animals" published by the National Institutes of Health (NIH publication 86-23, Revised 1986).

\subsection{Reagents}

Chloral hydrate, cyanamide, phenylephrine, $\mathrm{N}$-acetylcysteine and captopril were obtained from Sigma (St. Louis, MO, USA). Nitroglycerin was purchased from Beijing Yiming Pharmaceutical Factory (Beijing, China). DMEM was obtained from Gibco. Radioimmunoassay kits for the measurement of CGRP were obtained from Dongya Immunity Technology Institute (Beijing, China). Radioimmunoassay kits for the measurement of cGMP were purchased from Shanghai University of Chinese Medicine(Shanghai, China). Reactive oxygen species detection kit and BCA protein assay kit were purchased from Beyotime Company (Jiangsu, China).

\subsection{Nitroglycerin-induced tolerance model in vitro}

Rats were anesthetized with sodium pentobarbital $(60 \mathrm{mg} / \mathrm{kg}$, i.p.), and the thoracic aorta was rapidly isolated and cut into rings of $4 \mathrm{~mm}$ length. The rings were suspended horizontally between two stainless-steel wires and mounted in a 5-ml organ chamber filled with warmed $\left(37{ }^{\circ} \mathrm{C}\right)$ and oxygenated $\left(95 \% \mathrm{O}_{2}\right.$ and $5 \%$
$\left.\mathrm{CO}_{2}\right)$ Krebs solution. The Krebs solution had the following composition (mM): $\mathrm{NaCl}, 119.0 ; \mathrm{NaHCO}_{3}, 25.0 ; \mathrm{KCl}, 4.7$; $\mathrm{KH}_{2} \mathrm{PO}_{4}, 1.2 ; \mathrm{MgSO}_{4} \cdot 7 \mathrm{H}_{2} \mathrm{O}, 1.2 ; \mathrm{CaCl}_{2}, 2.5$; and glucose, 11.0. One of the ring ends was connected to a force transducer. The aortic ring was stretched with $2 \mathrm{~g}$ resting force, equilibrated for $60 \mathrm{~min}$, and then precontracted with $\mathrm{KCl}(60 \mathrm{mM})$. After a maximal response to $\mathrm{KCl}$ was obtained, the rings were washed repeatedly with Krebs solution and equilibrated again for $30 \mathrm{~min}$. At the end of the equilibration period, tolerance to nitroglycerin was induced by pretreatment with nitroglycerin $\left(10^{-5} \mathrm{M}\right)$ for $30 \mathrm{~min}$, and then the rings were washed repeatedly and equilibrated again for $1 \mathrm{~h}$. In order to measure vasodilator responses, rings were contracted with phenylephrine $\left(3 \times 10^{-6} \mathrm{M}\right)$ to $40-50 \%$ of their maximal concentration. After the constriction stabilized, accumulative concentration-response curve for nitroglycerin $\left(10^{-9}-10^{-4} \mathrm{M}\right)$ was obtained. For chloral hydrate and cyanamide, preparations were exposed to ALDH-2 inhibitor, chloral hydrate $(1 \mathrm{mM})$ or cyanamide $(1 \mathrm{mM})$, for $15 \mathrm{~min}$, respectively, and then treated with nitroglycerin in the presence of chloral hydrate or cyanamide.

\subsection{Nitroglycerin-induced tolerance model in vivo}

Tolerance was induced by treatment with nitroglycerin $(10 \mathrm{mg} / \mathrm{kg}$, s.c.) three times a day for 8 days and was confirmed by a reduction in hypotensive responses to intravenous nitroglycerin. In the control group, rat were given s.c. injection of $1 \%$ ethanol $(0.5 \mathrm{ml} / \mathrm{kg})$. After 8 days, the rats were anesthetized with sodium pentobarbital $(60 \mathrm{mg} / \mathrm{kg})$. A polyethylene (PE 50) catheter, contected with the blood pressure transducer, was inserted into the left femoral artery to record blood pressure. An additional catheter was inserted into the right femoral artery for the withdrawal of a reference arterial blood sample. Nitroglycerin $(150 \mathrm{mg} / \mathrm{kg})$ was administered through a cannula inserted into the right femoral vein. After surgical procedures, at least $10 \mathrm{~min}$ was allowed for stabilization. Blood

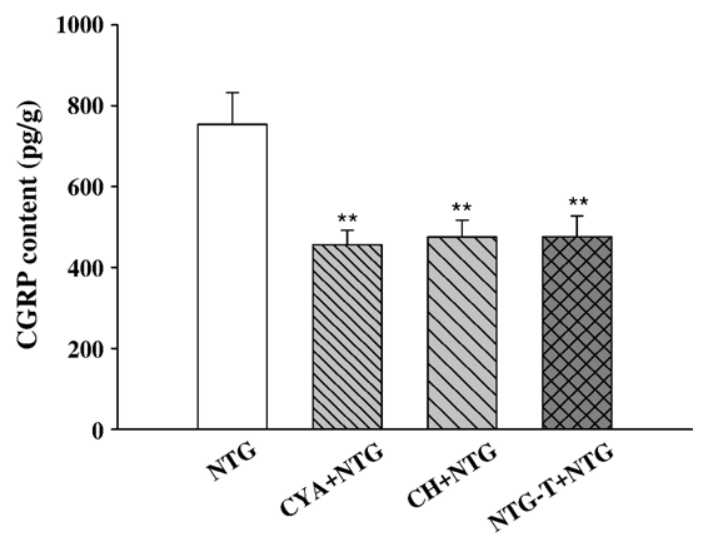

Fig. 2. Effect of nitroglycerin (NTG) on the release of CGRP from thoracic aortas. NTG: preparations were incubated with Krebs Solution and then exposed to NTG $\left(10^{-5} \mathrm{M}\right)$ for $10 \mathrm{~min}$. CYA $+\mathrm{NTG}$ or $\mathrm{CH}+\mathrm{NTG}$ : preparations were treated with $1 \mathrm{mM}$ chloral hydrate $(\mathrm{CH})$ or $1 \mathrm{mM}$ cyanamide (CYA) for $15 \mathrm{~min}$, respectively, and then exposed to NTG $\left(10^{-5} \mathrm{M}\right)$ for $10 \mathrm{~min}$. NTG-T+NTG: tolerance was induced by pretreatment with NTG $\left(10^{-5} \mathrm{M}\right)$ for $30 \mathrm{~min}$, and then the preparations were exposed to nitroglycerin $\left(10^{-5} \mathrm{M}\right)$. Values are expressed as means \pm S.E.M. $(n=10-15),{ }^{* *} P<0.01$ vs. Control; ${ }^{\# \#} P<0.01$ vs. NTG. 
Table 1

Baseline values of mean arterial pressure $(\mathrm{mm} \mathrm{Hg})$

\begin{tabular}{lll}
\hline & $n$ & Mean arterial pressure \\
\hline Control & 11 & $113.8 \pm 4.6$ \\
NTG & 11 & $123.8 \pm 5.0$ \\
CYA+NTG & 10 & $127.1 \pm 5.2$ \\
NTG-T+NTG & 10 & $118.7 \pm 4.4$ \\
\hline
\end{tabular}

Control: rats were given s.c. injection of $1 \%$ ethanol $(0.5 \mathrm{ml} / \mathrm{kg})$ three times a day for 8 days. Nitroglycerin (NTG): rats were given s.c. injection of $1 \%$ ethanol $(0.5 \mathrm{ml} / \mathrm{kg})$ three times a day for 8 days, and then NTG $(150 \mu \mathrm{g} / \mathrm{kg})$ was injected intravenously; NTG-T+NTG: rats were pretreated with NTG $(10 \mathrm{mg} / \mathrm{kg}$, s.c.) three times a day for 8 days, and then NTG $(150 \mu \mathrm{g} / \mathrm{kg})$ was injected intravenously. CYA + NTG: rats were given s.c. injection of $1 \%$ ethanol $(0.5 \mathrm{ml} /$ $\mathrm{kg}$ ) three times a day for 8 days, and treated with cyanamide $(31 \mathrm{mg} / \mathrm{kg}$, i.v. $)$ $15 \mathrm{~min}$ before injecting NTG $(150 \mu \mathrm{g} / \mathrm{kg})$ intravenously. Values are expressed as means \pm S.E.M

pressure was continuously monitored. The resulting electric signals were digitized by a MacLab analog-to-digital converter and recorded by a Power Macintosh 7220 computer. In the cyanamide plus nitroglycerin-treated group, cyanamide (31 mg/kg, i.v.) was given $15 \mathrm{~min}$ before the experiment.

\subsection{Measurement of CGRP-LI like concentration}

In vitro, thoracic aortas were incubated with nitroglycerin (final concentration $10^{-5} \mathrm{M}$ ) for $10 \mathrm{~min}$. Samples were collect and acetic acid was added (final concentration $0.2 \mathrm{mM}$ ). The samples were desalted on a Sep-Pak C18 cartridge and then eluted with $75 \%$ methanol containing $0.1 \%$ trifluoroacetic acid. Finally, samples were lyophilized and stored at $-70{ }^{\circ} \mathrm{C}$ until assay.

In vivo after a maximal depressor response to intravenous nitroglycerin was reached, blood samples $(3 \mathrm{ml})$ were collected rapidly from the right femoral artery into tubes containing $10 \%$ NaEDTA $40 \mu \mathrm{l}$ and aprotinin $500 \mathrm{mU} / \mathrm{L}$. The plasma was obtained by centrifugation at $3000 \mathrm{rpm}$ for $10 \mathrm{~min}$ at $4{ }^{\circ} \mathrm{C}$ and stored at $-70{ }^{\circ} \mathrm{C}$ until assayed.

CGRP-like immunoreactivity (CGRP-LI) was determined with radioimmunoassay kits using antisera raised against rat CGRP, ${ }^{125}$ I-labelled CGRP and rat CGRP standard.

\subsection{Cell culture}

Human umbilical vein endothelial cells (HUVEC, ATCC, CRL-2480) were cultured in Dulbecco's modified Eagle's medium (DMEM) containing 10\% (v/v) fetal bovine serum (FBS), $100 \mathrm{U} / \mathrm{ml}$ penicillin and $100 \mathrm{U} / \mathrm{ml}$ streptomycin. Cells were passaged into 6-well culture dishes and were serum-starved for $24 \mathrm{~h}$ in DMEM containing 1\% FBS when the cells had reached subconfluence. Then the cells were treated with nitroglycerin $\left(10^{-5} \mathrm{M}\right)$ for $4,8,16$ or $24 \mathrm{~h}$ or nitroglycerin $\left(3 \times 10^{-6}, 10^{-5}\right.$ or $3 \times 10^{-5} \mathrm{M}$ ) for $16 \mathrm{~h}$. In the $N$-acetylcysteine or captopril plus nitroglycerin tolerance group, cells were pretreated with $\mathrm{N}$ acetylcysteine $\left(10^{-2} \mathrm{M}\right)$ for $0.5 \mathrm{~h}$ or captopril $\left(10^{-5} \mathrm{M}\right)$ for $1 \mathrm{~h}$, and then exposed to nitroglycerin $\left(10^{-5} \mathrm{M}\right)$ for $16 \mathrm{~h}$ in the presence of $\mathrm{N}$-acetylcysteine or captopril. For cyanamide, endothelial cells were exposed to cyanamide $(1 \mathrm{mM})$ for $20 \mathrm{~min}$.

\subsection{Determination of reactive oxygen species generation}

Changes in the intracellular level of reactive oxygen species level were determined by measuring oxidative conversion of cellpermeable 2', 7'-dichlorofluorescein diacetate (DCFH-DA) into fluorescent dichlorofluorescein (DCF) in a fluorospectro-photometer (F4000, Japan). Cells were washed with D-Hank's buffer and incubated with DCFH-DA at $37^{\circ} \mathrm{C}$ for $20 \mathrm{~min}$. Then the DCF fluorescence of 20,000 cells was detected by fluorospectrophotometer analysis at an excitation wave length of $488 \mathrm{~nm}$ and an emission wave length of $535 \mathrm{~nm}$ (Jia et al., 2006).

\subsection{ALDH-2 activity assay}

Cells were collected with ice-cold phosphate-buffered saline (PBS) and their wet weight was determined. A 16.7\% (w/vol) cell suspension with $20 \mathrm{mM}$ ice-cold phosphate buffer (deoxygenated with nitrogen gas), $\mathrm{pH} 7.4$, containing $250 \mathrm{mM}$ sucrose was prepared. Cells were homogenized and centrifuged at $900 \mathrm{~g}$ for $5 \mathrm{~min}$ to collect the supernatant which was further centrifuged at $10,000 \mathrm{~g}$ for $10 \mathrm{~min}$ to collect the precipitated mitochondria. The mitochondria were dispersed in 5 vol ice-cold aqueous $30 \mathrm{mM}$ potassium phosphate buffer (deoxygenated with nitrogen gas), $\mathrm{pH}$ 7.5. The protein concentration was determined with BCA protein assay reagent. ALDH activity in the supernatant was measured at room temperature by following NADH formation at $340 \mathrm{~nm}$. The assay mixture $(1 \mathrm{ml})$ contained $100 \mathrm{mM}$ Tris- $\mathrm{HCl}$ ( $\mathrm{pH} 8.5), 1$ mM NAD ${ }^{-}, 1 \mathrm{mM}$ propionaldehyde and $1 \mathrm{mM}$ 4-methylpyrazole(Chen et al., 2002; Sydow et al., 2004; Ohsawa et al., 2003).

\subsection{Determination of cellular cGMP-LI like levels}

Cells in 6-well plates were washed two times with D-Hank's buffer and then were treated with $100 \mu \mathrm{M}$ nitroglycerin for $1 \mathrm{~min}$. The reaction was stopped by addition of $5 \%$ ice-cold

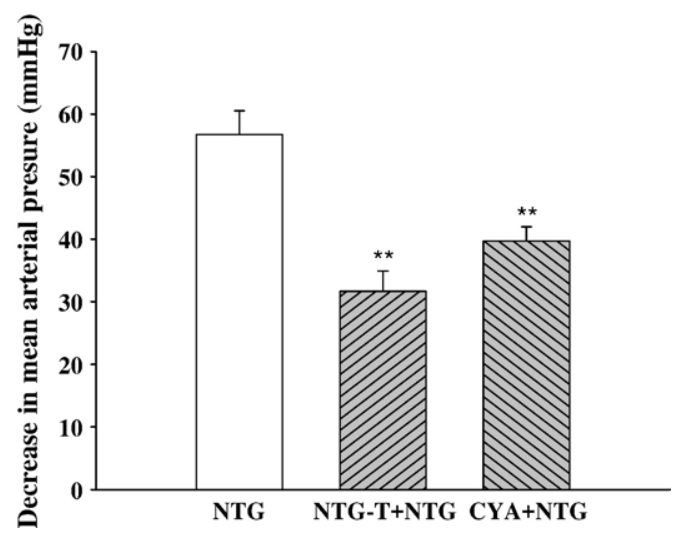

Fig. 3. Effect of nitroglycerin (NTG) on mean arterial pressure. NTG: rats were given s.c. injection of $1 \%$ ethanol $(0.5 \mathrm{ml} / \mathrm{kg})$ three times a day for 8 days, and then nitroglycerin $(150 \mu \mathrm{g} / \mathrm{kg})$ was injected intravenously. NTG-T+NTG: tolerance was induced by pretreatment with NTG $(10 \mathrm{mg} / \mathrm{kg}$, s.c.) three times a day for 8 days, and then NTG $(150 \mu \mathrm{g} / \mathrm{kg})$ was injected intravenously. CYA+ NTG: cyanamide (31 mg/kg,i.v.) was given $15 \mathrm{~min}$ before treatment with NTG. Values are means \pm S.E.M. $(n=10-11) . * * P<0.01$ vs. NTG. 


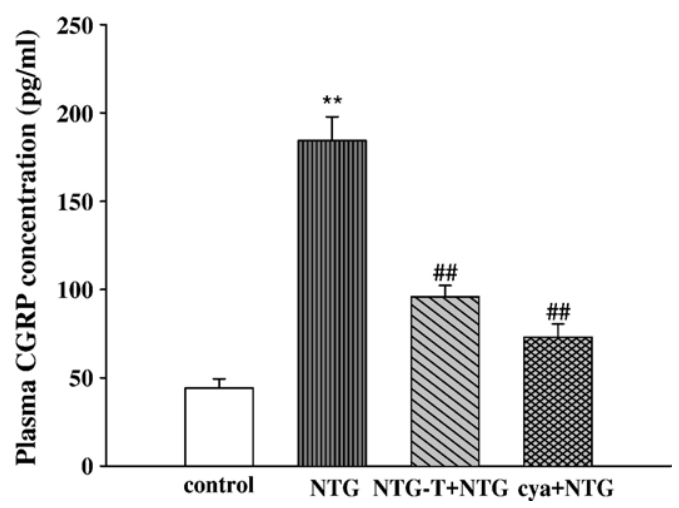

Fig. 4. Effect of nitroglycerin (NTG) on plasma concentrations of CGRP. Control: rats were given s.c. injection of $1 \%$ ethanol $(0.5 \mathrm{ml} / \mathrm{kg})$ three times a day for 8 days. NTG: rats were given s.c. injection of $1 \%$ ethanol $(0.5 \mathrm{ml} / \mathrm{kg})$ three times a day for 8 days, and then NTG $(150 \mu \mathrm{g} / \mathrm{kg})$ was injected intravenously; NTG-T+NTG: tolerance was induced by pretreatment with $\mathrm{NTG}(10 \mathrm{mg} / \mathrm{kg}$, s.c. $)$ three times a day for 8 days, and then NTG $(150 \mu \mathrm{g} / \mathrm{kg})$ was injected intravenously. CYA+NTG: rats were given s.c. injection of $1 \%$ ethanol $(0.5 \mathrm{ml} / \mathrm{kg})$ three times a day for 8 days, and then cyanamide $(31 \mathrm{mg} / \mathrm{kg}$, i.v.) was given $15 \mathrm{~min}$ before treatment with NTG. Values are means \pm S.E.M. $(n=10-11) .{ }^{* *} P<0.01$ vs. control; ${ }^{\# \#} P<0.01$ vs. NTG.

trichloroacetic acid. Measurement of cGMP was performed according to the manufacturer's protocol.

\subsection{Statistic analysis}

Results are expressed as means \pm S.E.M. All data were analyzed by ANOVA followed by the unpaired Student's $t$-test
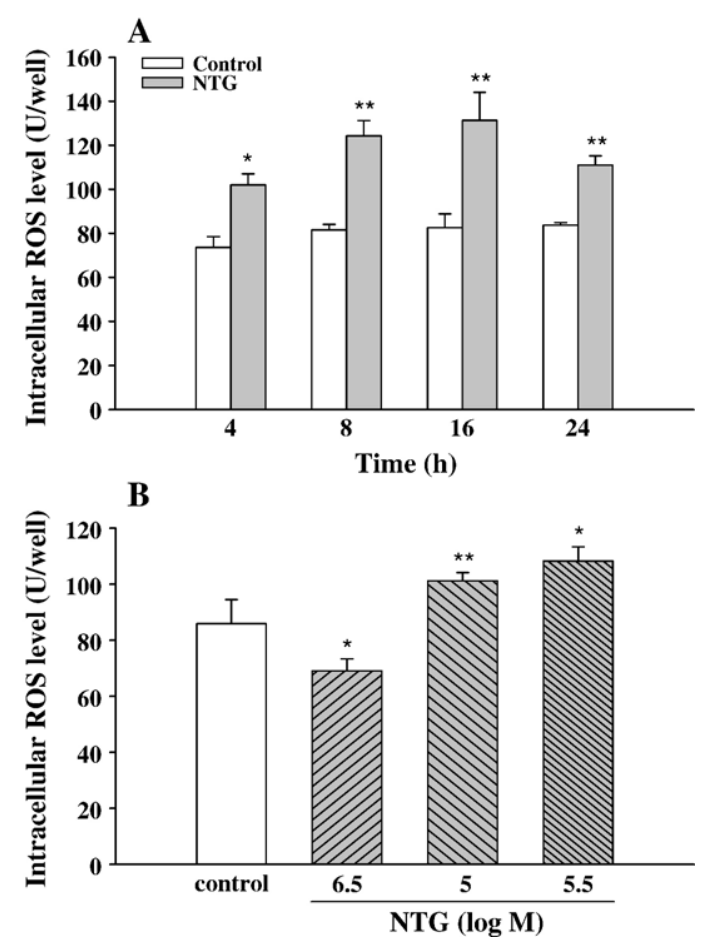

Fig. 5. Effect of nitroglycerin (NTG) on intracellular ROS production. Timeeffect reaction of NTG (A). NTG: endothelial cells were treated with NTG at the dose of $10 \mu \mathrm{M}$ for $4,8,16$ or $24 \mathrm{~h}$. Dose-effect reaction of NTG (B). NTG: endothelial cells were treated with NTG at the dose of 3,10 or $30 \mu \mathrm{M}$ for $16 \mathrm{~h}$. Values are means \pm S.E.M. $(n=4) . * P<0.05$ vs. control, $* * P<0.01$ vs. control.
Table 2

Effect of $\mathrm{N}$-acetylcysteine and captopril on intracellular ROS production (U/well)

\begin{tabular}{lc}
\hline & Intracellular ROS level \\
\hline Control & $82.17 \pm 5.68$ \\
NTG-T & $120.03 \pm 8.19^{\mathrm{a}}$ \\
NAC+NTG-T & $79.79 \pm 7.16^{\mathrm{b}}$ \\
CAP+NTG-T & $91.18 \pm 2.13^{\mathrm{b}}$ \\
NAC & $67.00 \pm 5.23$ \\
CAP & $81.04 \pm 7.71$ \\
\hline
\end{tabular}

NTG-T: tolerance was induced by incubation with nitroglycerin (NTG) $\left(10^{-5} \mathrm{M}\right)$ for $16 \mathrm{~h}$. NAC $+\mathrm{NTG}-\mathrm{T}$ or CAP $+\mathrm{NTG}-\mathrm{T}$ : endothelial cells were treated with $N$-acetylcysteine $(10 \mathrm{mM})$ for $0.5 \mathrm{~h}$ or captopril $\left(10^{-5} \mathrm{M}\right)$ for $1 \mathrm{~h}$ before NTG-induced tolerance. NAC or CAP: endothelial cells were treated with $N$-acetylcysteine $(10 \mathrm{mM})$ for $16.5 \mathrm{~h}$ or captopril $\left(10^{-5} \mathrm{M}\right)$ for $17 \mathrm{~h}$. Values are means \pm S.E.M. $(n=4)$.

a $P<0.01$ vs. control.

b $P<0.01$ vs. NTG-T.

for multiple comparisons. The significance level was chosen as $P<0.05$.

\section{Results}

\subsection{Vasodilator responses}

In presence of phenylephrine, nitroglycerin $\left(10^{-9}-10^{-4} \mathrm{M}\right)$ caused a concentration-dependent relaxation in the isolated rat thoracic aorta. Vasodilator responses to nitroglycerin were reduced in the presence of chloral hydrate or cyanamide. Chloral hydrate or cyanamide itself had no effect on constrictor responses to phenylephrine (data has not been shown). Preincubation of preparations with nitroglycerin $\left(10^{-5} \mathrm{M}\right)$ for $30 \mathrm{~min}$ markedly decreased vasodilator responses to nitroglycerin (Fig. 1).

\subsection{The release of CGRP from thoracic aortas}

As shown in Fig. 2, nitroglycerin increased the release of CGRP from thoracic aortas. The release of CGRP induced by nitroglycerin was attenuated by pretreatment with chloral hydrate, cyanamide, or nitroglycerin $\left(10^{-5} \mathrm{M}\right)$ for $30 \mathrm{~min}$ (Fig. 2).

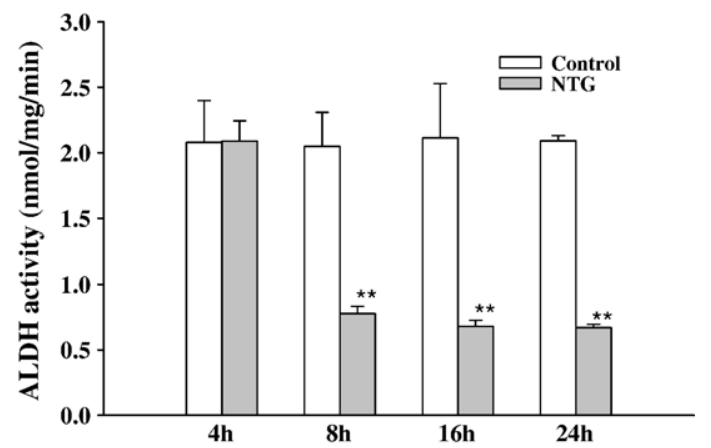

Fig. 6. Effects of nitroglycerin (NTG) on intracellular ALDH activity. NTG: endothelial cells were treated with NTG at the dose of $10 \mu \mathrm{M}$ for $4,8,16$ or $24 \mathrm{~h}$. Values are means \pm S.E.M. $(n=4)$. ${ }^{* *} P<0.01$ vs. control. 
Table 3

Effects of $N$-acetylcysteine and captopril on intracellular ALDH activity (nmol/ $\mathrm{mg} / \mathrm{min}$ )

\begin{tabular}{ll}
\hline Groups & Intracellular ALDH activity \\
\hline Control & $2.11 \pm 0.41$ \\
NTG-T & $0.68 \pm 0.05^{\mathrm{a}}$ \\
NAC+NTG-T & $2.37 \pm 0.34^{\mathrm{b}}$ \\
CAP+NTG-T & $2.42 \pm 0.31^{\mathrm{b}}$ \\
NAC & $1.55 \pm 0.21$ \\
CAP & $1.59 \pm 0.31$ \\
\hline
\end{tabular}

NTG-T: tolerance was induced by incubation with $10^{-5} \mathrm{M}$ nitroglycerin (NTG) for $16 \mathrm{~h}$. NAC+NTG-T or CAP+NTG-T: endothelial cells were exposed to $\mathrm{N}$ acetylcysteine $(10 \mathrm{mM})$ for $0.5 \mathrm{~h}$ or captopril $\left(10^{-5} \mathrm{M}\right)$ for $1 \mathrm{~h}$ before NTG-induced tolerance. NAC or CAP: endothelial cells were exposed to $\mathrm{N}$-acetylcysteine $(10 \mathrm{mM})$ for $16.5 \mathrm{~h}$ or captopril $\left(10^{-5} \mathrm{M}\right)$ for $17 \mathrm{~h}$.

a $P<0.01$ vs. control.

b $P<0.01$ vs. NTG-T.

\subsection{Depressor effects}

There were no differences in basal values of blood pressure among the groups (Table 1). Nitroglycerin $(150 \mu \mathrm{g} / \mathrm{kg}$, i.v.) significantly decreased blood pressure. The depressor effect of nitroglycerin was almost completely abolished in the tolerant rats. Pretreatment with cyanamide also reduced the depressor effect of nitroglycerin (Fig. 3).

\subsection{Concentrations of CGRP}

Nitroglycerin significantly increased plasma concentrations of CGRP. However, the release of CGRP stimulated by nitroglycerin was reduced in the tolerant rats, and after pretreatment with cyanamide (Fig. 4).

\subsection{Concentrations of reactive oxygen species}

Exposure of endothelial cells to nitroglycerin at the dose of $10^{-6}, 10^{-5}$ or $3 \times 10^{-5} \mathrm{M}$ for $16 \mathrm{~h}$ or $10^{-5} \mathrm{M}$ for $4,8,16$ or $24 \mathrm{~h}$ significantly increased the intracellular level of reactive oxygen species (Fig. 5). Pretreatment with $\mathrm{N}$-acetylcysteine (10 mM) or

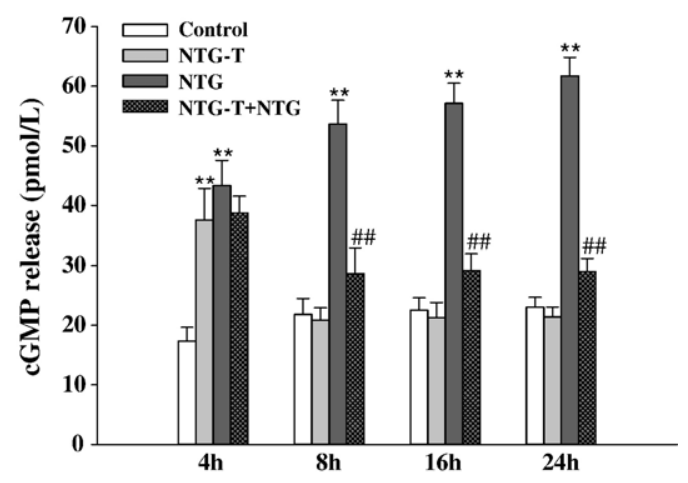

Fig. 7. Effects of nitroglycerin (NTG) on the intracellular cGMP level. NTG-T: endothelial cells were treated with NTG at the dose of $10 \mu \mathrm{M}$ for $4,8,16$ or $24 \mathrm{~h}$; NTG: endothelial cells were treated with NTG $(100 \mu \mathrm{M})$ for $1 \mathrm{~min}$. NTG-T+ NTG: endothelial cells were treated with NTG at the dose of $10 \mu \mathrm{M}$ for 4,8 , 16 or $24 \mathrm{~h}$ and then stimulated with NTG $\left(10^{-4} \mathrm{M}\right)$ for $1 \mathrm{~min}$. Values are means \pm S.E.M. $(n=4)$. ${ }^{* *} P<0.01$ vs. control; ${ }^{\# \#} P<0.01$ vs. NTG-T.
Table 4

Effects of $N$-acetylcysteine and captopril on intracellular cGMP level (pmol/L)

\begin{tabular}{ll}
\hline Groups & Intracellular cGMP level \\
\hline Control & $33.71 \pm 1.94$ \\
NTG-T & $30.64 \pm 1.94$ \\
NTG & $70.48 \pm 10.26^{\mathrm{a}}$ \\
NTG-T+NTG & $42.76 \pm 2.79^{\mathrm{b}}$ \\
NAC+NTG-T+NTG & $59.76 \pm 3.69^{\mathrm{c}}$ \\
CAP+NTG-T+NTG & $51.48 \pm 1.58^{\mathrm{c}}$ \\
NAC+NTG-T & $26.65 \pm 8.28$ \\
CAP+NTG-T & $25.35 \pm 8.17$ \\
\hline
\end{tabular}

NTG-T: tolerance was induced by incubation with $10^{-5} \mathrm{M}$ nitroglycerin (NTG) for $16 \mathrm{~h}$. NTG: endothelial cells were treated with NTG $\left(10^{-4} \mathrm{M}\right)$ for $1 \mathrm{~min}$. NTG-T+NTG: endothelial cells were treated with NTG $\left(10^{-4} \mathrm{M}\right)$ for $1 \mathrm{~min}$ after NTG-induced tolerance. NAC $+\mathrm{NTG}-\mathrm{T}+\mathrm{NTG}$ or $\mathrm{CAP}+\mathrm{NTG}-\mathrm{T}+\mathrm{NTG}$ : endothelial cells were treated with $N$-acetylcysteine $(10 \mathrm{mM})$ for $0.5 \mathrm{~h}$ or captopril $\left(10^{-5} \mathrm{M}\right)$ for $1 \mathrm{~h}$ before NTG-induced tolerance, and then treated with NTG $\left(10^{-4} \mathrm{M}\right)$ for $1 \mathrm{~min}$. NAC $+\mathrm{NTG}-\mathrm{T}$ or CAP $+\mathrm{NTG}-\mathrm{T}$ : endothelial cells were treated with $N$-acetylcysteine $(10 \mathrm{mM})$ for $0.5 \mathrm{~h}$ or captopril $\left(10^{-5} \mathrm{M}\right)$ for $1 \mathrm{~h}$ before NTG-induced tolerance. Values are means \pm S.E.M. $(n=4)$.

a $P<0.01$ vs. control.

b $P<0.01$ vs. NTG.

c $P<0.01$ vs. NTG-T+NTG.

captopril $(10 \mu \mathrm{M})$ attenuated the increased level of reactive oxygen species induced by nitroglycerin (Table 2). $\mathrm{N}$-acetylcysteine or captopril itself had no effect on the intracellular level of reactive oxygen species (data has not been shown).

\subsection{Activity of ALDH-2}

ALDH2 activity was significantly decreased in the endothelial cells treated with nitroglycerin $\left(10^{-5} \mathrm{M}\right)$ for 8,16 or $24 \mathrm{~h}$ (Fig. 6). $N$-acetylcysteine $(10 \mathrm{mM})$ or captopril $(10 \mu \mathrm{M})$ significantly attenuated the decreased activity of ALDH2 induced by nitroglycerin (Table 3). However, $N$-acetylcysteine or captopril itself had no effect on the activity of ALDH-2 (data has not been shown).

\subsection{Concentrations of cGMP}

Pretreatment with nitroglycerin $\left(10^{-5} \mathrm{M}\right)$ for 8,16 or $24 \mathrm{~h}$ significantly decreased the cGMP formation induced by acute

Table 5

Effects of ALDH2 inhibitors on intracellular cGMP level (pmol/L)

\begin{tabular}{ll}
\hline & Intracellular cGMP level \\
\hline Control & $19.91 \pm 1.80$ \\
NTG-T & $18.78 \pm 2.23$ \\
NTG & $64.70 \pm 2.76^{\mathrm{a}}$ \\
CYA+NTG & $55.68 \pm 2.14^{\mathrm{b}}$ \\
NTG-T+NTG & $40.07 \pm 1.69^{\mathrm{b}}$
\end{tabular}

NTG-T: tolerance was induced by pretreatment with $10^{-5} \mathrm{M}$ nitroglycerin (NTG) for $16 \mathrm{~h}$. NTG: endothelial cells were treated with NTG $\left(10^{-4} \mathrm{M}\right)$ for 1 min. CYA + NTG: endothelial cells were exposed to cyanamide $\left(10^{-3} \mathrm{M}\right)$ for $20 \mathrm{~min}$ and then treated with NTG $\left(10^{-4} \mathrm{M}\right)$ for $1 \mathrm{~min}$. NTG-T+NTG: endothelial cells were treated with NTG $\left(10^{-4} \mathrm{M}\right)$ for 1 min after NTG-induced tolerance. Values are means \pm S.E.M. $(n=4)$.

${ }^{\text {a }} P<0.01$ vs. control.

b $P<0.01$ vs. NTG. 
treatment with nitroglycerin $\left(10^{-4} \mathrm{M}\right)$ (Fig. 7). Exposure to cyanamide $\left(10^{-3} \mathrm{M}\right)$ for $20 \mathrm{~min}$ also significantly reduced nitroglycerin-induced cGMP formation (Table 5). $\mathrm{N}$-acetylcysteine $(10 \mathrm{mM})$ or captopril $(10 \mu \mathrm{M})$ reversed nitroglycerininduced tolerance (Table 4). $\mathrm{N}$-acetylcysteine, captopril or cyanamide itself had no effect on the nitroglycerin-induced cGMP formation in tolerant endothelial cells (data has not been shown).

\section{Discussion}

Previous studies have suggested that nitroglycerin activates capsaicin sensitive sensory nerves to release CGRP (Wei et al., 1992; Hu et al., 1999; Zhou et al., 2001a; Du et al., 2004; Ghatta and O'Rourke, 2006). The present results showed that nitroglycerin caused a concentration-dependent relaxation and a depressor effect, concomitantly with an increase in the release of CGRP in isolated rat thoracic aorta and in the concentration of CGRP in plasma. We and others have demonstrated that the vasodilator responses and depressor effect of nitroglycerin are attenuated or abolished by CGRP-(0-37), the CGRP receptor antagonist, or capsaicin, which selectively depletes CGRP in sensory nerves (Wei et al., 1992; Zhou et al., 2001a,c). It has been reported that methylene blue, an inhibitor of soluble guanylate cyclase, abolishes the increased release of CGRP produced by nitroglycerin (Zhou et al., 2001a). These findings support the hypothesis that the cardiovascular effect of nitroglycerin is, at least partially, mediated by endogenous CGRP via the cGMP pathway.

It has been demonstrated that frequently repeated or continuous exposure to high doses of organic nitrates leads to a marked attenuation of the magnitude of most of their pharmacological effects. However, the mechanism responsible for tolerance to organic nitrates is not fully understood. Proposed mechanisms include oxidative stress, inhibition of nitroglycerin-metabolizing enzyme, endothelial dysfunction, changes in nitroglycerin signaling or endogenous active substances, and so on (Munzel et al., 2005).

Oxidative stress may be a decisive component in the development of nitrate tolerance (Munzel et al., 1999; Jurt et al., 2001; Csont and Ferdinandy, 2005; Wenzel et al., 2007). Recent studies have indicated that ALDH-2 is the main enzyme responsible for nitroglycerin bioactivation, and that inhibition of this enzyme contributes to nitrate tolerance (Chen et al., 2002; Sydow et al., 2004). There is evidence that oxidants can inactivate ALDH-2 directly and induce nitrate tolerance (Sydow et al., 2004; Wenzel et al., 2007). Oxidative stress may contribute directly to nitroglycerin tolerance, either by oxidative inhibition of ALDH-2 or perhaps by oxidizing key enzyme cofactors (Chen et al., 2002; Sydow et al., 2004; Daiber et al., 2004; Munzel et al., 2005). The present study confirmed previous observations that pretreatment of the isolated rat thoracic aorta with ALDH-2 inhibitors significantly attenuated the vasodilation and depressor effect of nitroglycerin (Chen et al., 2002; Sydow et al., 2004). In cultured endothelial cells, nitroglycerin tolerance increased the level of reactive oxygen species and attenuated ALDH-2 activity as well as cGMP production in a time-and concentration-dependent manner, and an ALDH-2 inhibitor significantly reduced nitroglycerininduced cGMP formation, which was attenuated by antioxidants, $\mathrm{N}$-acetylcysteine or captopril (a SH-containing compound). Collectively, these data provide strong support for the suggestion that nitrate tolerance is due to stimulation of reactive oxygen species production, thereby decreasing the activity of mitochondrial ALDH-2 and resulting in the decreased production of cGMP.

Previous investigations have demonstrated that tolerance to nitroglycerin is related to the decreased release of CGRP (Oroszi et al., 1999; Zhou et al., 2001b; Ghatta and O'Rourke, 2006). The results of this study confirmed previous observations that vasodilator responses to nitroglycerin in vitro and the depressor effect and release of CGRP induced by nitroglycerin in vivo are decreased in nitrate tolerance.

As mentioned above, the development of tolerance to nitroglycerin is associated with the desensitization of mitochondrial ALDH-2 (Chen et al., 2002; Sydow et al., 2004), leading to an attenuated rise in cGMP, and nitroglycerin regulates CGRP release through the cGMP pathway (Zhou et al., 2001a; Booth et al., 2000). Thus, we postulate that the decreased release of CGRP in nitrate tolerance may involve the mitochondrial ALDH-2 pathway. The results of this study revealed that the effect of nitroglycerin, causing vasodilator responses as well as a depressor effect concomitantly with an increase in the release of CGRP, were attenuated by pretreatment with an ALDH-2 inhibitor. Our studies also showed that $\mathrm{N}$-acetylcysteine or captopril, which has antioxidant activity, reversed the tolerance to nitroglycerin concomitantly with an increase in the release of CGRP and an increase in the activity of mitochondrial ALDH-2 by decreasing reactive oxygen species production. These findings support the hypothesis that the decreased release of CGRP in nitrate tolerance is related to the reduced activity of mitochondrial ALDH-2.

In summary, the present study suggests that the decrease release of endogenous CGRP release in nitroglycerin tolerance may be related to a decrease in ALDH-2 activity as a result of stimulation of reactive oxygen species formation.

\section{Acknowledgements}

This work was supported by a grant from the Ministry of Education, China.

\section{References}

Booth, B.P., Tabrizi-Fard, M.A., Fung, H., 2000. Calcitonin gene-related peptide-dependent vascular relaxation of rat aorta. An additional mechanism for nitroglycerin. Biochem. Pharmacol. 15, 1603-1609.

Csont, T., Ferdinandy, P., 2005. Cardioprotective effects of glyceryl trinitrate: beyond vascular nitrate tolerance. Pharmacol. Ther. 105, 57-68.

Du, Y.H., Peng, J., Huang, Z.Z., Jiang, D.J., Deng, H.W., Li, Y.J., 2004. Delayed cardioprotection afforded by nitroglycerin is mediated by alpha-CGRP via activation of inducible nitric oxide synthase. Int. J. Cardiol. 93, 49-54.

Chen, Z., Zhang, J., Stamler, J.S., 2002. Identification of the enzymatic mechanism of nitroglycerin bioactivation. Proc. Natl. Acad. Sci. 99, 8306-8311. 
Daiber, A., Oelze, M., Coldewey, M., Bachschmid, M., Wenzel, P., Sydow, K., Wendt, M., Kleschyov, A.L., Stalleicken, D., Ullrich, V., Mulsch, A., Munzel, T., 2004. Oxidative stress and mitochondrial aldehyde dehydrogenase activity: a comparison of pentaerythritol tetranitrate with other organic nitrates. Mol. Pharmacol. 66, 1372-1382.

Franco-Cereceda, A., 1988. Calcitonin gene-related peptide and tachykinins in relation to local sensory control of cardiac contractility and coronary vascular tone. Acta Physiol. Scand., Suppl. 569, 1-63.

Ghatta, S., O'Rourke, S.T., 2006. Nitroglycerin-induced release of calcitonin gene-related peptide from sensory nerves attenuates the development of nitrate tolerance. J. Cardiovasc. Pharmacol. 47, 175-181.

Hu, C.P., Li, Y.J., Deng, H.W., 1999. The cardioprotective effects of nitroglycerin-induced preconditioning are mediated by calcitonin generelated peptide. Eur. J. Pharmacol. 369, 189-194.

Jia, S.J., Jiang, D.J., Hu, C.P., Zhang, X.H., Deng, H.W., Li, Y.J., 2006 Lysophosphatidylcholine-induced elevation of asymmetric dimethylarginine level by the NADPH oxidase pathway in endothelial cells. Vascul. Pharmacol. 44, 143-148.

Jurt, U., Gori, T., Ravandi, A., Babaei, S., Zeman, P., Parker, J.D., 2001. Differential effects of pentaerythritol tetranitrate and nitroglycerin on the development of tolerance and evidence of lipid peroxidation: a human in vivo study. J. Am. Coll. Cardiol. 38, 854-859.

Katsuki, S., Arnold, W.P., Murad, F., 1977. Effects of sodium nitroprusside nitroglycerin, and sodium azide on levels of cyclic nucleotides and mechanical activity of various tissues. J Cyclic. Nucleotide Res. 3 (4), 239-247.

Munzel, T., Hink, U., Yigit, H., Macharzina, R., Harrison, D.G., Mulsch, A., 1999. Role of superoxide dismutase in in vivo and in vitro nitrate tolerance. Br. J. Pharmacol. 127, 1224-1230.
Munzel, T., Daiber, A., Mulsch, A., 2005. Explaining the phenomenon of nitrate tolerance. Circ. Res. 30, 618-628.

Ohsawa, I., Nishimaki, K., Yasuda, C., Kamino, K., Ohta, S., 2003. Deficiency in a mitochondrial aldehyde dehydrogenase increases vulnerability to oxidative stress in PC12 cells. J. Neurochem. 84, 1110-1117.

Oroszi, G., Szilvassy, Z., Nemeth, J., Ferdinandy, J., Szolcsanyi, J., Tosaki, A., 1999. Interaction between capsaicin and nitrate tolerance in isolated guineapig heart. Eur. J. Pharmacol. 368, R1-R3.

Sydow, K., Daiber, A., Oelze, M., Chen, Z., August, M., Wendt, M., Ullrich, V., Mulsch, A., Schulz, E., Keaney Jr., J.F., Stamler, J.S., Munzel, T., 2004. Central role of mitochondrial aldehyde dehydrogenase and reactive oxygen species in nitroglycerin tolerance and cross-tolerance. J. Clin. Invest. 113, 482-489.

Wei, E.P., Moskowitz, M.A., Boccalini, P., Kontos, H.A., 1992. Calcitonin generelated peptide mediates nitroglycerin and sodium nitroprusside-induced vasodilation in feline cerebral arterioles. Circ. Res. 70, 1313-1319.

Wenzel, P., Hink, U., Oelze, M., Schuppan, S., Schaeuble, K., Schildknecht, S., Ho, K.K., Weiner, H., Bachschmid, M., Munzel, T., Daiber, A., 2007. Role of reduced lipoic acid in the redox regulation of mitochondrial aldehyde dehydrogenase (ALDH-2) activity Implications for mitochondrial oxidative stress and nitrate tolerance. J. Biol. Chem. 282, 792-799.

Zhou, Z.H., Deng, H.W., Li, Y.J., 2001a. The depressor effect of nitroglycerin is mediated by calcitonin gene-related peptide. Life. Sci. 69, 1313-1320.

Zhou, Z.H., Deng, H.W., Li, Y.J., 2001b. Involvement of calcitonin gene-related peptide in the development of tolerance to nitroglycerin in the rat. Eur. J. Pharmacol. 427, 137-141.

Zhou, Z.H., Deng, H.W., Li, Y.J., 2001c. Involvement of calcitonin gene-related peptide in nitroglycerin induced improvement of preservation with cardioplegic solution. Acta. Pharmacol. Sin 22, 141-147. 